\title{
L'organisation andine du savoir rituel et technique en termes d'espace et de temps
}

R. Tom Zuidema

\section{(2) OpenEdition \\ 12 Journals}

Édition électronique

URL : https://journals.openedition.org/tc/929

DOI : $10.4000 /$ tc.929

ISSN : 1952-420X

Éditeur

Éditions de l'EHESS

\section{Édition imprimée}

Date de publication : 1 février 1986

ISSN : 0248-6016

\section{Référence électronique}

R. Tom Zuidema, «L'organisation andine du savoir rituel et technique en termes d'espace et de temps », Techniques \& Culture [En ligne], 6 | 1986, mis en ligne le 24 janvier 2006, consulté le 29 septembre 2022. URL : http://journals.openedition.org/tc/929 ; DOI : https://doi.org/10.4000/tc.929

Ce document a été généré automatiquement le 29 septembre 2022.

Tous droits réservés 
L'organisation andine du savoir rituel et technique en termes d'espace et de temps

R. Tom Zuidema 